\title{
Topical Hypochlorous Acid (HOCl) as a Potential Treatment of Pruritus
}

\author{
Robert Y. Pelgrift • Adam J. Friedman
}

Published online: 3 July 2013

(C) Springer Science+Business Media New York 2013

\begin{abstract}
Topical hypochlorous acid ( $\mathrm{HOCl}$ ) has recently been proposed as a treatment of pruritus. However, it is not known whether topical $\mathrm{HOCl}$ decreases or promotes pruritus. This review sheds light on this poorly understood subject. This article describes the pathophysiology of pruritus, current treatments of pruritus, and how $\mathrm{pH}$ determines the properties of $\mathrm{HOCl}$ in solution. The article then proposes two mechanisms by which $\mathrm{HOCl}$ may reduce pruritus: 1) $\mathrm{HOCl}$ is microbicidal to cutaneous pathogens, especially Staphylococcus aureus in atopic dermatitis; 2) $\mathrm{HOCl}$ is anti-inflammatory and reduces the activities of histamine, leukotriene B4, and interleukin-2, all of which are implicated in the pathophysiology of itch. Lastly, this article describes conditions under which $\mathrm{HOCl}$ may actually cause pruritus as an adverse effect. For example, $\mathrm{HOCl}$ increases the activity of nerve growth factor, which promotes itch. Prolonged or high-dose $\mathrm{HOCl}$ exposure may also cause irritant contact dermatitis, or less commonly, allergic contact dermatitis.
\end{abstract}

Keywords Hypochlorous acid · $\mathrm{HOCl} \cdot$ Hypochlorite $\mathrm{NaOCl} \cdot \mathrm{Bleach} \cdot \mathrm{Itch} \cdot$ Pruritus $\cdot$ Treatment $\cdot$ Therapy Topical $\cdot$ Atopic dermatitis $\cdot$ Staphylococcus aureus · Bactericidal $\cdot$ Microbicidal $\cdot$ Inflammation $\cdot$ Histamine $\cdot$ Leukotriene B4 · Interleukin-2 · Nerve growth factor .

\section{R. Y. Pelgrift \\ Albert Einstein College of Medicine, 1300 Morris Park Avenue, Bronx, NY 10461, USA \\ e-mail: robert.pelgrift@med.einstein.yu.edu}

\section{A. J. Friedman $(\bowtie)$}

Division of Dermatology, Department of Medicine, Albert Einstein College of Medicine, Montefiore Medical Center, 111 E. 210th

Street, Bronx, NY 10467, USA

e-mail: adfriedm@montefiore.org

\section{A. J. Friedman}

Department of Physiology and Biophysics, Albert Einstein College of Medicine, 1300 Morris Park Avenue, Bronx, NY 10461, USA
Contact dermatitis · Irritation $\cdot \mathrm{pH} \cdot$ Allergic .

Hypersensitivity $\cdot$ Urticaria

\section{Introduction}

Pruritus is the most common symptom seen in dermatologic disease and has a significantly negative impact upon patient quality of life $[1 \bullet, 2 \bullet \cdot]$. Recently, topical hypochlorous acid $(\mathrm{HOCl})$ has been proposed as a treatment of pruritus [ $3 \bullet \bullet$. However, it is not known definitively whether topical $\mathrm{HOCl}$ decreases or promotes pruritus, because so little research has been published on this topic to date [3••]. This review article sheds light on this subject by combining information from current literature on pruritus and literature on $\mathrm{HOCl}$. This article consists of five parts. The first discusses the pathophysiology of itch, while the second discusses current treatments of itch. The third part of this review explains how the properties of $\mathrm{HOCl}$ in solution depend strongly on the solution's $\mathrm{pH}$. In the fourth part, using available literature on pruritus and literature on $\mathrm{HOCl}$, we propose the following two mechanisms by which $\mathrm{HOCl}$ may reduce pruritus: 1) $\mathrm{HOCl}$ is microbicidal to cutaneous pathogens, especially Staphylococcus aureus in atopic dermatitis [3••]; 2) $\mathrm{HOCl}$ is anti-inflammatory and reduces the activities of histamine, leukotriene B4 (LTB4), and interleukin-2 (IL-2), all of which have been implicated in the pathophysiology of itch $[1 \bullet, 4 \cdot$, $5,6 \bullet]$. Lastly, in the interest of patient safety, we describe conditions under which $\mathrm{HOCl}$ may actually cause pruritus as an adverse effect. For example, $\mathrm{HOCl}$ increases the activity of nerve growth factor (NGF), which promotes itch $[4 \bullet, 5]$. Prolonged exposure or high doses of $\mathrm{HOCl}$ may also result in irritant contact dermatitis, and less commonly in allergic contact dermatitis (which is a Type IV hypersensitivity reaction). This stresses the importance of delivery in order to translate $\mathrm{HOCl}$ to the bedside [7]. 


\section{Pathophysiology of Itch}

Pruritus is defined as an uncomfortable sensation that causes the wish to scratch $[2 \bullet, 4 \bullet]$. Pruritus is sensed in the epidermis (whose removal completely stops cutaneous itch sensation), mucous membranes, or cornea, but no other tissue types [5]. Acute itch lasts from seconds to 1 week, whereas chronic itch lasts for more than 6 weeks and is the subject of this paper [2••]. There are four types of itch: Psychogenic, neurogenic, neuropathic, and pruritoceptive pruritus $[1 \bullet, 4 \bullet]$. Each type of itch is described below.

Psychogenic pruritus is an urge of psychiatric etiology to scratch physically normal skin, and is a diagnosis of exclusion [1•]. Psychogenic itch can be associated with psychological disorders, such as somatoform disorders, substance abuse, psychosis, mania, depression, stress, anxiety, obsessive compulsive disorder, and delusional parasitosis $[1 \bullet, 2 \bullet \bullet, 4 \bullet]$.

Neurogenic itch is pruritus whose afferent pathway includes the central nervous system (CNS), but neurogenic itch is always secondary to disease occurring outside of the skin $[1 \bullet, 4 \cdot, 8]$. These diseases include hematologic disorders (e.g., polycythemia vera), lymphoproliferative diseases (e.g., leukemia, Hodgkin lymphoma, Sezary syndrome), cholestasis (often due to hepatic disease), endocrine diseases, chronic kidney disease (CKD), or iatrogenic opioid-induced pruritus [1 $2 \bullet \bullet, 4 \cdot, 8]$. In contrast to neuropathic pruritus, neuronal damage does not play a role in the pathophysiology of neurogenic pruritus [1•]. Possible etiologies of neurogenic itch include pruritogens in the bloodstream (e.g., cholestatic pruritus) or endogenous intraspinal opioids $[1 \bullet, 4 \bullet]$.

Neuropathic itch is pruritus due to damage to peripheral or central neurons located anywhere in the afferent pathway of itch sensation, resulting in over-activation of the itch pathway that is independent of normal stimuli for itch $[1 \bullet, 4 \bullet]$. For example, damage to $\mathrm{C}$-fibers might cause an increase in their firing rate, thereby over-activating the afferent itch pathway [1•]. Alternatively, a lesion might cause neurons in the spinothalamic tract that normally inhibit itch sensation to decrease their firing rate [1•]. Neuropathic itch is rarely relieved by scratching and often occurs concomitantly with paresthesia, hypoesthesia, or hyperesthesia $[1 \bullet]$. Neuropathic itch can be secondary to post-herpetic neuralgia, notalgia paresthetica, brachioradial pruritus, peripheral nervous system (PNS) tumors, or CNS tumors $[1 \bullet, 4 \bullet]$.

Pruritoceptive itch is pruritus due to stimuli in the epidermis, which activate the entire afferent pathway of itch sensation [1•]. This pathway is triggered when compromised function of the epidermal skin barrier (which occurs more commonly at night), inflammation, or age-related skin changes cause release into the epidermis of pruritogens $[1 \bullet$ $2 \bullet \bullet, 5]$. These pruritogens bind to and activate receptors on the termini of free nerve endings of C-fibers in the epidermal stratum granulosum $[1 \bullet, 5,9]$. It is unknown whether this occurs in $\mathrm{C}$-fibers alone, or if keratinocytes are similarly activated and then interact with adjacent $\mathrm{C}$-fibers $[1 \bullet, 5]$. Table 1 lists some of these receptors expressed in the epidermis by $\mathrm{C}$-fibers and possibly by keratinocytes, their corresponding pruritogenic agonists, and associated pruritic diseases whose pathogenesis involves these receptor-agonist pairs $[1 \bullet, 4 \cdot 5,10]$. Note that $\mathrm{HOCl}$ reduces the activities of three of these pruritogenic agonists (histamine, LTB4, and IL-2), but increases the activity of one of them (NGF) $[1 \bullet, 4 \cdot$, $5,6 \bullet]$. The sensory neurons that project these $\mathrm{C}$-fibers peripherally have their somas located in the dorsal root ganglia and project axons centrally into the spinothalamic tract $\left[1^{\bullet}\right]$. After activation of any of the receptors listed in Table 1, the afferent itch signal travels through these sensory neurons, through the spinothalamic tract to the thalamus, and to the somatosensory cortex $[1 \cdot, 4 \cdot, 8]$.

\section{Current Treatment of Itch}

Currently, treatment of pruritus is based on only a small number of studies with small sample sizes, which are mostly case series, usually without controls, and usually not double blinded $[2 \bullet \bullet$. Table 2 summarizes currently available treatments of chronic pruritus, their mechanisms of action, pruritic diseases in which they are indicated, and common adverse effects. Topical treatments are used for mild or localized pruritus, whereas systemic treatments are used for severe or generalized pruritus [ $2 \bullet \cdot]$. If an underlying cause of pruritus can be identified, then treating the causative disease often decreases the pruritus $[2 \bullet \bullet$.

\section{The Properties of HOCl in Solution Depend Upon pH}

The properties of $\mathrm{HOCl}$ in solution are strongly linked to the solution's $\mathrm{pH}$. This is because $\mathrm{pH}$ changes can cause $\mathrm{HOCl}$ to react, resulting in mixtures of $\mathrm{HOCl}$ in equilibrium with various reaction products [11]. Therefore, evaluation of the biochemical and clinical effects of $\mathrm{HOCl}$ should, whenever possible, take into account the $\mathrm{pH}$ and reaction products with which $\mathrm{HOCl}$ is in equilibrium [12]. One problem with the current literature on $\mathrm{HOCl}$ is that $\mathrm{pH}$ is often not considered.

In aqueous $0.9 \% \mathrm{Na}+\mathrm{Cl}$ - solution (which has the same osmolality as human plasma [13]), $\mathrm{pH}$ changes cause $\mathrm{HOCl}$ to react as follows [11]:

When $\mathrm{pH}<3.5$, decreases in $\mathrm{pH}$ drive forward the following three reactions (displayed below with their equilibrium constants), in which $\mathrm{HOCl}$ reacts and forms $\mathrm{Cl}_{2}(\mathrm{aq}), \mathrm{Cl}_{2}(\mathrm{~g})$, 
Table 1 Receptors that mediate itch, corresponding pruritogenic agonists, associated pruritic diseases whose pathogenesis involves the receptoragonist pair, and agents to treat itch that target the receptor or the agonist $[1 \bullet, 2 \cdot \bullet, 4 \bullet, 5,10,26,27,37,38,40]$

\begin{tabular}{|c|c|c|c|}
\hline Receptor & Pruritogenic agonist & $\begin{array}{l}\text { Associated with pruritus in } \\
\text { the following diseases }\end{array}$ & Agent used to treat itch \\
\hline \multicolumn{4}{|l|}{$\begin{array}{l}\text { Receptors expressed in the epidermis } \\
\text { by C-fibers (and possibly by } \\
\text { keratinocytes): }\end{array}$} \\
\hline H1 GPCR ${ }^{a}$ & Histamine & Urticaria & $\begin{array}{l}\text { 1st and 2nd generation } \mathrm{H} 1 \\
\text { antihistamines }^{\mathrm{b}} \text {, doxepin }\end{array}$ \\
\hline $\mathrm{H} 4 \mathrm{GPCR}^{\mathrm{a}}$ & Histamine & Urticaria & N/A \\
\hline $\begin{array}{l}\text { Nicotinic acetylcholine-gated } \\
\text { cation channels }{ }^{\text {a }}\end{array}$ & Acetylcholine & Atopic dermatitis & $\mathrm{N} / \mathrm{A}$ \\
\hline Muscarinic GPCRs $^{\text {a }}$ & Acetylcholine & Atopic dermatitis & N/A \\
\hline Leukotriene B4 (LTB4) GPCR ${ }^{\text {a }}$ & Leukotriene B4 (LTB4) & Atopic dermatitis & Zileuton $^{\mathrm{d}}$ \\
\hline Neurokinin 1 (NK1) GPCR ${ }^{\mathrm{a}}$ & $\begin{array}{l}\text { Tachykinins, including: } \\
\text { Substance P }\end{array}$ & $\begin{array}{l}\text { Atopic dermatitis, psoriasis, } \\
\text { Sezary syndrome }\end{array}$ & Aprepitant ${ }^{\mathrm{c}}$ \\
\hline Interleukin-2 receptor $(\mathrm{IL}-2 \mathrm{R})^{\mathrm{a}}$ & Interleukin-2 (IL-2) & Atopic dermatitis & $\begin{array}{l}\text { Cyclosporine }{ }^{\mathrm{e}} \text {, topical } \\
\text { calcineurin inhibitors } \\
\text { (tacrolimus and }^{\mathrm{e}} \\
\text { pimecrolimus) }^{\mathrm{e}}\end{array}$ \\
\hline $\begin{array}{l}\text { Interleukin-31 JAK-linked } \\
\text { receptor (IL-31R) }{ }^{\text {a }}\end{array}$ & Interleukin-31 (IL-31) & $\begin{array}{l}\text { Atopic dermatitis, prurigo } \\
\text { nodularis, familial primary } \\
\text { localized cutaneous amyloidosis }\end{array}$ & Anti-IL-31 antibody \\
\hline $\begin{array}{l}\text { Protease-activated receptor-2 } \\
\text { (PAR2) GPCR }{ }^{\text {a }}\end{array}$ & $\begin{array}{l}\text { Several different proteases }{ }^{\mathrm{f}} \text {, } \\
\text { including: Kallikreins, tryptase, } \\
\text { cathepsin S, protease allergens } \\
\text { from dust mites and cockroaches, } \\
\text { and cowhage }\end{array}$ & Atopic dermatitis & $\begin{array}{l}\text { Topical agents with low } \mathrm{pH} \\
\text { decrease serine protease } \\
\text { activity, decreasing PAR2 } \\
\text { activity }\end{array}$ \\
\hline $\begin{array}{l}\text { TRP vanilloid receptor-1 } \\
\text { (TRPV1) ligand-gated ion } \\
\text { channel }^{\mathrm{g}}\end{array}$ & Unknown & Prurigo nodularis & Capsaicin $^{\mathrm{h}}$ \\
\hline $\begin{array}{l}\text { Tropomyosin-related kinase A } \\
\text { (TrkA) receptor tyrosine kinase }\end{array}$ & Nerve growth factor (NGF) & $\begin{array}{l}\text { Atopic dermatitis, psoriasis, } \\
\text { prurigo nodularis }\end{array}$ & N/A \\
\hline Prostanoid receptors ${ }^{j}$ & $\begin{array}{l}\text { Prostaglandin E (PGE), } \\
\text { thromboxane } \mathrm{A}_{2}\left(\mathrm{TxA}_{2}\right)\end{array}$ & Atopic dermatitis & Topical or oral salicylates ${ }^{k}$ \\
\hline \multicolumn{4}{|l|}{ Intraspinal receptors: } \\
\hline $\begin{array}{l}\text { Increased } \mu \text {-opioid GPCR activity } \\
\text { (which promotes itch) relative } \\
\text { to } \kappa \text {-opioid GPCR activity } \\
\text { (which inhibits itch) }\end{array}$ & Opioid peptides & $\begin{array}{l}\text { Cholestatic pruritus, iatrogenic } \\
\text { opioid-induced pruritus, } \\
\text { atopic dermatitis }\end{array}$ & $\begin{array}{l}\text { Naloxone }{ }^{1}, \text { naltrexone }{ }^{1}, \\
\quad \text { nalmefene }{ }^{1} \text {, butorphanol }\end{array}$ \\
\hline
\end{tabular}

GPCR denotes a G protein coupled receptor;

${ }^{\mathrm{a}}$ This receptor triggers the itch pathway upon binding agonist; ${ }^{\mathrm{b}}$ Receptor inverse agonist; ${ }^{\mathrm{c}}$ Receptor antagonist; ${ }^{\mathrm{d}}$ Acts by decreasing leukotriene B4 synthesis; ${ }^{\mathrm{e}}$ Acts by decreasing IL-2 synthesis; ${ }^{\mathrm{f}}$ This list includes serine proteases whose activity is increased by high epidermal $\mathrm{pH}$ (eg. due to high $\mathrm{pH}$ in antibacterial soap) and decreased by low epidermal $\mathrm{pH} ;{ }^{\mathrm{g}}$ Does not trigger itch, but TRPV1 expression is necessary for histamine and serotonin to cause itch; ${ }^{\mathrm{h}}$ Acts by binding to TRPV1 of C-fiber, causing depletion of neuropeptides in that C-fiber; ${ }^{\mathrm{i}}$ Does not trigger itch, but decreases itch threshold of skin; ${ }^{\mathrm{j}}$ Does not trigger itch, but sensitizes other receptors to itch; ${ }^{\mathrm{k}}$ Acts by inhibiting cyclooxygenase (COX), thereby decreasing synthesis of prostanoids, including PGE and $\mathrm{TxA}_{2} ;{ }^{1} \mu$-opioid antagonist; ${ }^{\mathrm{m}}$ Combined $\mu$-opioid antagonist and $\mathrm{K}$-opioid agonist

and $\mathrm{Cl}_{3}$ - (aq) [11]. Therefore, when $\mathrm{pH}<3.5$, decreases in $\mathrm{pH}$ result in a mixture of decreasing concentrations of $\mathrm{HOCl}(\mathrm{aq})$ and increasing concentrations of $\mathrm{Cl}_{2}(\mathrm{aq}), \mathrm{Cl}_{2}(\mathrm{~g})$, and $\mathrm{Cl}_{3}-$ (aq) $[11]$ :

$$
\begin{array}{ll}
\mathrm{HOCl}(\mathrm{aq})+\mathrm{Cl}-(\mathrm{aq})+\mathrm{H}+(\mathrm{aq}) \rightleftarrows \mathrm{Cl}_{2}(\mathrm{aq})+\mathrm{H}_{2} \mathrm{O}(1) & \mathrm{K}_{1}=9.6 \times 10^{2} \mathrm{M}^{-2} \\
\mathrm{Cl}_{2}(\mathrm{aq}) \rightleftarrows \mathrm{Cl}_{2}(\mathrm{~g}) & \mathrm{K}_{2}=10.87 \mathrm{~atm} \mathrm{M}^{-1} \\
\mathrm{Cl}_{2}(\mathrm{aq})+\mathrm{Cl}-(\mathrm{aq}) \rightleftarrows \mathrm{Cl}_{3}-(\mathrm{aq}) & \mathrm{K}_{3}=0.18 \mathrm{M}^{-1}
\end{array}
$$


Table 2 Current treatment of chronic pruritus $[1 \bullet, 2 \bullet \bullet, 4 \bullet, 5,38-40]$

\begin{tabular}{|c|c|c|c|}
\hline Agent & $\begin{array}{l}\text { Mechanism of action in } \\
\text { treating itch }\end{array}$ & $\begin{array}{l}\text { Indicated for pruritus in the } \\
\text { following diseases }\end{array}$ & Adverse effects \\
\hline \multicolumn{4}{|l|}{ Topical agents for itch: ${ }^{\mathrm{a}}$} \\
\hline $\begin{array}{l}\text { Moisturizers, emollients, } \\
\text { barrier repair creams }\end{array}$ & $\begin{array}{l}\text { Improves function of the } \\
\text { epidermal skin barrier }\end{array}$ & $\begin{array}{l}\mathrm{AD}^{\mathrm{b}} \text {, itch due to dry skin, nocturnal } \\
\text { pruritus }\end{array}$ & N/A \\
\hline $\begin{array}{l}\text { Menthol }(1-3 \%) \text { cream or } \\
\text { lotion }\end{array}$ & $\begin{array}{l}\text { Agonist of TRPM } 8 \\
\text { ligand-gated ion channel, } \\
\text { which causes cooling } \\
\text { sensation }\end{array}$ & $\begin{array}{l}\text { Any case of pruritus that is relieved by } \\
\text { cooling sensation }\end{array}$ & $\begin{array}{l}\text { Menthol concentrations above } \\
1-3 \% \text { can cause irritation. }\end{array}$ \\
\hline Topical salicylates (2-6 \%) & Inhibits $\mathrm{PG}^{\mathrm{c}}$ synthesis & Neurodermatitis & $\begin{array}{l}\mathrm{CI}^{\mathrm{d}} \text { in children and acute } \\
\text { inflammatory dermatoses }\end{array}$ \\
\hline Topical glucocorticoids ${ }^{\mathrm{e}}$ & $\begin{array}{l}\text { Decreases inflammation of } \\
\text { skin }\end{array}$ & $\begin{array}{l}\text { Inflammatory dermatoses only } \\
\text { (e.g. } \mathrm{AD}^{\mathrm{b}} \text {, psoriasis) }\end{array}$ & $\begin{array}{l}\text { Skin atrophy, telangiectasia, } \\
\text { HPA }^{\mathrm{f}} \text { suppression. }\end{array}$ \\
\hline $\begin{array}{l}\text { Topical calcineurin inhibitors } \\
\text { (TCIs): Tacrolimus ointment } \\
\text { or pimecrolimus cream }\end{array}$ & $\begin{array}{l}\text { Decreases IL-2 synthesis; } \\
\text { TRPV } 1^{\mathrm{g}} \text { may also be } \\
\text { involved. }\end{array}$ & $\begin{array}{l}\mathrm{AD}^{\mathrm{b}}, \mathrm{PN}^{\mathrm{h}}, \text { irritant contact dermatitis, } \\
\text { anogenital pruritus, graft versus } \\
\text { host disease, lichen sclerosis }\end{array}$ & $\begin{array}{l}\text { Stinging and burning } \\
\text { sensations }\end{array}$ \\
\hline Doxepin (5\%) cream & $\begin{array}{l}\text { Has H1 GPCR antagonist } \\
\text { activity }\end{array}$ & $\begin{array}{l}\mathrm{AD}^{\mathrm{b}} \text {, contact dermatitis, nummular } \\
\text { dermatitis, neurodermatitis }\end{array}$ & $\begin{array}{l}\text { Burning sensation, allergic } \\
\text { contact dermatitis, sedation. } \\
\mathrm{CI}^{\mathrm{d}} \text { in children. }\end{array}$ \\
\hline Lidocaine $(5 \%)$ patch & Local anesthetic & Neuropathic pruritus & N/A \\
\hline Topical pramoxine $(1 \%)$ & Local anesthetic & $\mathrm{CKD}^{\mathrm{i}}$, facial pruritus & N/A \\
\hline $\begin{array}{l}\text { Topical polidocanol } \\
\qquad(3 \%)+\text { urea }(5 \%)\end{array}$ & $\begin{array}{l}\text { Local anesthetic and } \\
\text { moisturizer }\end{array}$ & $\mathrm{AD}^{\mathrm{b}}$, contact dermatitis, psoriasis & N/A \\
\hline Capsaicin $(.025-.1 \%)$ cream & $\begin{array}{l}\text { Binds to TRPV } 1^{\mathrm{g}} \text { of } \mathrm{C} \text {-fiber, } \\
\text { causing depletion of } \\
\text { neuropeptides in } \mathrm{C} \text {-fiber }\end{array}$ & $\begin{array}{l}\mathrm{PN}^{\mathrm{h}} \text {, aquagenic pruritus, } \mathrm{CKD}^{\mathrm{i}} \text {, } \\
\text { neuropathic itch. }\end{array}$ & $\begin{array}{l}\text { Intense burning sensation } \\
\text { during the first few days } \\
\text { of treatment }\end{array}$ \\
\hline $\begin{array}{l}\text { N-palmitoylethanolamine } \\
\text { cream } \\
\text { Systemic agents for itch: }\end{array}$ & $\begin{array}{l}\text { CB2 cannabinoid receptor } \\
\text { agonist }\end{array}$ & $\mathrm{AD}^{\mathrm{b}}, \mathrm{PN}^{\mathrm{h}}$, neurodermatitis, $\mathrm{CKD}^{\mathrm{i}}$ & N/A \\
\hline $\begin{array}{l}\text { Oral } 1 \text { st and } 2 \text { nd generation } \\
\text { H1 antihistamines }\end{array}$ & H1 GPCR inverse agonist & Urticaria & $\begin{array}{l}\text { 1st generation } \mathrm{H} 1 \\
\text { antihistamines: } \\
\text { Sedation. }\end{array}$ \\
\hline Oral salicylates & Inhibits $\mathrm{PG}^{\mathrm{c}}$ synthesis & Polycythemia vera & N/A \\
\hline Aprepitant & $\mathrm{NK} 1{ }^{\mathrm{j}}$ GPCR antagonist & Sezary syndrome & N/A \\
\hline Intravenous lidocaine (5 \%) & Anesthetic & Cholestatic pruritus & N/A \\
\hline Mirtazapine & $\begin{array}{l}\text { Antagonist of the following } \\
\text { receptors: alpha2, 5-HT2, } \\
\text { 5-HT3, H1 }\end{array}$ & $\begin{array}{l}\text { Nocturnal pruritus, } \mathrm{AD}^{\mathrm{b}} \text {, Leukemia, } \\
\text { lymphoma, } \mathrm{CKD}^{\mathrm{i}} \text {, cholestatic } \\
\text { pruritus }\end{array}$ & $\begin{array}{l}\text { Increased appetite, weight gain, } \\
\text { sedation }\end{array}$ \\
\hline Paroxetine or fluvoxamine & $\mathrm{SSRI}^{\mathrm{k}}$ & $\mathrm{AD}^{\mathrm{b}}$, paraneoplastic itch & $\mathrm{N} / \mathrm{A}$ \\
\hline Sertraline & $\mathrm{SSRI}^{\mathrm{k}}$ & Cholestatic pruritus & $\mathrm{N} / \mathrm{A}$ \\
\hline Gabapentin & $\begin{array}{l}\text { Inhibits transmission of } \\
\text { afferent itch signal to brain }\end{array}$ & $\begin{array}{l}\text { Neuropathic itch, CKD }{ }^{\mathrm{i}} \text {, Sezary } \\
\text { syndrome }\end{array}$ & $\begin{array}{l}\text { Drowsiness, weight gain. } \\
\text { CI }^{d} \text { in cholestatic } \\
\text { pruritus }\end{array}$ \\
\hline Naltrexone or nalmefene & $\mu$-opioid GPCR antagonist & $\begin{array}{l}\text { Cholestatic pruritus, } \mathrm{CKD}^{\mathrm{i}} \\
\mathrm{AD}^{\mathrm{b}} \text {, urticaria, burns }\end{array}$ & Nausea, vomiting, drowsiness \\
\hline Butorphanol & $\begin{array}{l}\mu \text {-opioid antagonist and } \\
\kappa \text {-opioid agonist activity }\end{array}$ & Nocturnal pruritus, intractable pruritus & Nausea, vomiting, drowsiness \\
\hline Nalfurafine & $\kappa$-opioid GPCR agonist & $\mathrm{CKD}^{\mathrm{i}}$ & Insomnia \\
\hline Oral cyclosporine ${ }^{\mathrm{e}}$ & Decreases IL-2 synthesis & Refractory itch in $\mathrm{AD}^{\mathrm{b}}$ & $\begin{array}{l}\text { HTN }^{1}, \text { nephrotoxicity, } \\
\text { immunosuppression }\end{array}$ \\
\hline Oral azathioprine ${ }^{\mathrm{e}}$ & Toxicity to lymphocytes & Refractory itch in $\mathrm{AD}^{\mathrm{b}}$ & Myelosuppression \\
\hline
\end{tabular}

GPCR denotes a G protein coupled receptor

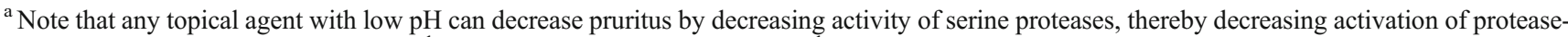
activated receptor-2 (PAR2) GPCR; ${ }^{\mathrm{b}}$ Atopic dermatitis; ${ }^{\mathrm{c}}$ Prostanoid; ${ }^{\mathrm{d}}$ Contraindicated ; ${ }^{\mathrm{e}}$ Prolonged duration of use is contraindicated; ${ }^{\mathrm{f}}$ Hypothalamus-anterior pituitary-adrenal cortex axis; ${ }^{\mathrm{g}}$ TRP vanilloid receptor-1 ligand-gated ion channel; ${ }^{\mathrm{h}}$ Prurigo nodularis; ${ }^{\mathrm{i}} \mathrm{Chronic}$ kidney disease; ${ }^{\mathrm{j}}$ Neurokinin $1 \mathrm{GPCR} ;{ }^{\mathrm{k}}$ Selective serotonin reuptake inhibitor; ${ }^{1}$ Hypertension 
At $\mathrm{pH}$ between 3.5 and $5.5, \mathrm{HOCl}$ is stable [11].

When $\mathrm{pH}>5.5$, increases in $\mathrm{pH}$ drive forward the following reaction (displayed below with its $\mathrm{pKa}$ ), in which $\mathrm{HOCl}$ is deprotonated and forms - $\mathrm{OCl}$ (aq) [11]. Therefore, when $\mathrm{pH}>5.5$, increases in $\mathrm{pH}$ result in a mixture of decreasing concentrations of $\mathrm{HOCl}(\mathrm{aq})$ and increasing concentrations of $-\mathrm{OCl}$ (aq) [11]:

$$
\mathrm{HOCl}(\mathrm{aq}) \rightleftarrows \mathrm{H}+(\mathrm{aq})+-\mathrm{OCl}(\mathrm{aq}) \quad \mathrm{pKa}=7.5
$$

In general, $\mathrm{HOCl}$ is more reactive than -OCl [12]. Therefore, relative to - $\mathrm{OCl}, \mathrm{HOCl}$ is more powerful as an irritant of skin, antimicrobial agent, and stain remover when used on laundry in commercial bleach [12]. Solution containing $\mathrm{HOCl}$ and $-\mathrm{OCl}$ in equilibrium is often made by dissolving sodium hypochlorite $(\mathrm{NaOCl})$ in $\mathrm{H}_{2} \mathrm{O}$. Therefore, the sum of the concentrations of $\mathrm{HOCl}$ and $-\mathrm{OCl}$ is often quoted as \% $\mathrm{NaOCl}$, which equals 100 times the ratio of the mass of $\mathrm{NaOCl}$ dissolved in solution to the total mass of solution [14].

\section{Mechanisms by which HOCI May Decrease Pruritus}

To date, the only clinical study specifically testing the effect of topical $\mathrm{HOCl}$ treatment on severity of pruritus is a recent poster by Draelos et al. [3••]. In this case series (which lacked controls), 20 human subjects with atopic dermatitis received 7 days of treatment with topical hydrogel containing $0.008 \% \mathrm{HOCl}$ and $0.002 \% \mathrm{NaOCl}[3 \cdot \bullet$, 15]. Severity of pruritus was measured using a visual analogue scale reported by subjects, a 5-point ordinal scale reported by subjects, and a 5-point ordinal scale reported by the investigator [3••]. By all measurements taken, there was a statistically significant decrease in severity of pruritus at day 3 of treatment $[3 \bullet \cdot$. During days $4-7$, skin barrier repair foam was included in the treatment regimen, and further reductions in pruritus were reported [3••].

Despite these promising results, it is not known definitively whether $\mathrm{HOCl}$ decreases or promotes pruritus, because so little research has been published on this topic to date [3・•]. Moreover, if $\mathrm{HOCl}$ is anti-pruritic, its exact mechanism of action has yet to be elucidated [3••]. However, by correlating the current body of knowledge on pruritus with information on $\mathrm{HOCl}$, we propose mechanisms by which $\mathrm{HOCl}$ may have anti-pruritic effects, as well as conditions under which $\mathrm{HOCl}$ may actually cause pruritus as an adverse effect. Specifically, $\mathrm{HOCl}$ may reduce pruritus by either of the following two mechanisms: 1) $\mathrm{HOCl}$ is microbicidal to cutaneous pathogens, especially Staphylococcus aureus in atopic dermatitis [3••]; 2) $\mathrm{HOCl}$ is anti-inflammatory and reduces the activities of histamine, LTB4, and IL-2, all of which have been implicated in the pathophysiology of itch $[1 \cdot 4 \cdot, 5,6 \bullet]$. However, interestingly, $\mathrm{HOCl}$ increases the activity of NGF, which enhances itch $[4 \cdot, 5]$. Moreover, prolonged exposure or high doses of $\mathrm{HOCl}$ may promote pruritus by causing irritant contact dermatitis, or less commonly, allergic contact dermatitis (which is a Type IV hypersensitivity reaction) [7].

\section{Microbicidal Activity of $\mathrm{HOCl}$}

$\mathrm{HOCl}$ may reduce pruritus because it is microbicidal to cutaneous pathogens that exacerbate pruritic diseases, especially Staphylococcus aureus on the skin of atopic dermatitis patients $[3 \bullet \bullet$.

The microbicidal effect of $\mathrm{HOCl}$ plays a central role when $\mathrm{HOCl}$ is produced during the human innate immune response. When myeloperoxidase-expressing cells (including neutrophils, monocytes, and, under certain conditions, macrophages $[16,17])$ phagocytose pathogens, $\mathrm{HOCl}$ is produced in the phagosome by the respiratory burst pathway, which consists of the following three reactions $[6 \bullet, 11,18 \bullet]$ :

$2 \mathrm{O}_{2}+\mathrm{NADPH}(\mathrm{H}+) \stackrel{\text { NADPH oxidase }}{\longrightarrow} 2 . \mathrm{O}_{2}-($ superoxide $)+2 \mathrm{H}++\mathrm{NADP}+$

$2 . \mathrm{O}_{2}-($ superoxide $)+2 \mathrm{H}+\stackrel{\begin{array}{c}\text { no catalyst,or superoxide dismutase } \\ \text { activity of myeloperoxidase }\end{array}}{\longrightarrow} \mathrm{H}_{2} \mathrm{O}_{2}$ (hydrogen peroxide) $+\mathrm{O}_{2}$

$\mathrm{H}_{2} \mathrm{O}_{2}$ (hydrogen peroxide $)+\mathrm{Cl}-+\mathrm{H}+\stackrel{\begin{array}{c}\text { chlorination activity } \\ \text { of myeloperoxidase }\end{array}}{\longrightarrow} \mathrm{HOCl}($ hypochlorous acid $)+\mathrm{H}_{2} \mathrm{O}$

The resulting $\mathrm{HOCl}$ undergoes reactions with various functional groups of proteins, including chlorination of amino groups and oxidation of thiol groups of cys residues, thioether groups of met residues, disulfide groups, trp residues, and heme groups $[11,18 \bullet, 19,20]$. These reactions make HOCl microbicidal, because, among other antimicrobial mechanisms, they damage 
the electron transport chain and cause depletion of adenine nucleotides [18•,21]. When most of the bactericidal activity occurs, $\mathrm{pH}=7.4-7.8$ in the phagosome $[18 \bullet]$. $\mathrm{HOCl}$ has $\mathrm{pKa}$ of 7.5 , so this $\mathrm{pH}$ range implies by the Henderson-Hasselbalch equation that the $[\mathrm{HOCl}] /[-\mathrm{OCl}]$ ratio in the phagosome is between $1.3\left(=10^{7.5-7.4}\right)$ and $0.50\left(=10^{7.5-7.8}\right)$ when most bacteria are killed $[11,22]$. Concentrations between 0.169 and $2.73 \mu \mathrm{g} / \mathrm{mL}$ of $\mathrm{HOCl}$ are microbicidal in vitro to fungi, such as Candida albicans, and to many species of bacteria, including methicillin-sensitive (MSSA) and methicillin-resistant (MRSA) Staphylococcus aureus, Staphylococcus epidermidis, Staphylococcus saprophyticus, Streptococcus pyogenes, vancomycin-resistant Enterococcus faecium, Serratia marcescens, Escherichia coli, Enterobacter aerogenes, Klebsiella pneumoniae, Proteus mirabilis, Pseudomonas aeruginosa, and Haemophilus influenzae [11, 19].

Staphylococcus aureus overgrowth on skin is the most common cause of exacerbation of atopic dermatitis [23••]. This exacerbation occurs partly because $\mathrm{S}$. aureus releases superantigens, which increase inflammation in skin lesions $[23 \bullet \bullet$. Therefore, disease severity of atopic dermatitis can be reduced if the amount of S. aureus on the skin is decreased [23.•]. Use of antibiotics increases the likelihood of development of bacterial drug resistance [23••]. Therefore, bleach baths, in which low concentrations of $\mathrm{NaOCl}$ are dissolved in bathwater, are a potential alternative or adjuvant treatment to decrease cutaneous S. aureus levels [23・•]. The review by Barnes et al. [23••] summarizes the four clinical studies published to date, providing evidence that dilute bleach baths ranging from 0.004 to $0.016 \% \mathrm{NaOCl}$ (used concomitantly with intranasal mupirocin) reduce severity of disease in atopic dermatitis complicated by S. aureus overgrowth on skin [23••].

\section{Net Anti-Inflammatory Effect of $\mathrm{HOCl}$}

$\mathrm{HOCl}$ might decrease pruritus by reducing inflammation. $\mathrm{HOCl}$ has both anti-inflammatory effects and proinflammatory effects, which are described immediately below [19]. Altogether, the anti-inflammatory effects outweigh the pro-inflammatory effects, so that the net effect of $\mathrm{HOCl}$ is anti-inflammatory [19]. This net anti-inflammatory effect by itself may reduce pruritus $[2 \bullet \cdot]$. We emphasize that $\mathrm{HOCl}$ reduces the activities of several pro-inflammatory chemical messengers that have been implicated in the pathophysiology of itch (See Table 1), including histamine (associated with urticaria), LTB4 (associated with atopic dermatitis), and IL-2 (associated with atopic dermatitis) $[1 \bullet, 4 \bullet, 5,6 \bullet]$. However, we also note that $\mathrm{HOCl}$ increases the activity of NGF, which promotes itch and is associated with atopic dermatitis, psoriasis, and prurigo nodularis $[4 \cdot, 5]$.

$\mathrm{HOCl}$ has multiple anti-inflammatory effects, including the following:
1) $\mathrm{HOCl}$ adds one or more $\mathrm{Cl}$ groups to the $\mathrm{NH}_{2}$ group of histamine, thereby converting histamine to a histamine-N-choramine and decreasing the activity of histamine $[6 \cdot 19]$.

2) Oxidation by $\mathrm{HOCl}$ of thiol or thioether groups directly decreases the activity of leukotrienes released by neutrophils (including sulfidopeptidic-leukotriene C4sulfoxide and 6-trans-leukotriene B4) and of interleukin6 (IL-6) $[6 \cdot 19]$.

3) Oxidation by $\mathrm{HOCl}$ of thiol or thioether groups directly increases the activity of transforming growth factor-beta (TGF-beta), which is anti-inflammatory [19, 24].

4) Oxidation by $\mathrm{HOCl}$ of thiol groups may cause phosphorylation and hence activation of receptor tyrosine kinases, which causes increased synthesis of growth factors [19].

5) At high concentrations, $\mathrm{HOCl}$ decreases the activities of the following proteases: matrix metalloproteinase-7 (MMP-7) (because $\mathrm{HOCl}$ oxidizes adjacent trp and gly residues at the catalytic site of MMP-7), collagenases (if the $\mathrm{HOCl} /$ collagenase ratio $>40$ ), and possibly gelatinases (if the $\mathrm{HOCl} /$ gelatinase ratio $>30$ ) [19]. We could not find information on whether matrix metalloproteinases (MMPs), collagenases, or gelatinases are agonists of the protease-activated receptor-2 (PAR2), whose activation has been implicated in the pathophysiology of itch (as discussed in Tables 1 and 2) $[1 \bullet, 2 \bullet \bullet, 4 \bullet, 5]$. However, we note that the PAR2 receptor is activated by a diverse array of proteases (See Table 1$)[1 \bullet, 5]$. If MMP-7, collagenases, or gelatinases are PAR2 agonists, then the reduction in their activities in response to high $\mathrm{HOCl}$ concentrations might be another mechanism by which $\mathrm{HOCl}$ could reduce pruritus.

6) Alpha2-macroglobulin is a plasma protein that binds to and neutralizes signaling molecules [19]. $\mathrm{HOCl}$ oxidizes alpha2-macroglobulin, which causes an increase in the binding affinity (and hence neutralizing activity) of alpha2-macroglobulin for pro-inflammatory cytokines, including tumor necrosis factor-alpha (TNF-alpha), IL2 , and IL-6 $[6 \cdot, 19]$. Oxidation by $\mathrm{HOCl}$ of alpha2macroglobulin also decreases the binding affinity (and hence neutralizing activity) of alpha2-macroglobulin for growth factors, including beta-nerve growth factor (betaNGF), platelet-derived growth factor-BB (PDGF-BB), TGF-beta1, and TGF-beta2 [19].

7) $\mathrm{HOCl}$ chlorinates proteinaceous parts of antigens, which causes decreased activity of the innate immune system against Gram positive bacteria, but increased activity against Gram negative bacteria [19].

As mentioned above, $\mathrm{HOCl}$ also has several proinflammatory effects: 
1) Whereas high concentrations of $\mathrm{HOCl}$ decrease protease activities, low concentrations of $\mathrm{HOCl}$ increase the activities of the following proteases by oxidizing the thiol groups of their cys residues: MMPs, collagenases (if the $\mathrm{HOCl} /$ collagenase ratio<40), and gelatinase B [19]. As mentioned above, we were not able to find any information on whether MMPs, collagenases, or gelatinases agonize the PAR2 receptor or cause pruritus.

2) Oxidation by $\mathrm{HOCl}$ of alpha2-macroglobulin may also decrease the binding affinity (and hence neutralizing activity) of alpha2-macroglobulin for cell proteases [19]. Again, we do not know whether these cell proteases agonize the PAR2 receptor or are associated with pruritus.

3) Oxidation by $\mathrm{HOCl}$ of met residues might also increase activity of $\mathrm{c} 5$ of the complement pathway [19].

4) $\mathrm{HOCl}$ increases binding of macrophages to endothelium and increases permeability of blood vessels by increasing the size of spaces between endothelial cells $[19,25]$.

5) Oxidation by $\mathrm{HOCl}$ of thiol groups may cause phosphorylation and hence activation of receptor tyrosine kinases, which causes increased synthesis of pro-inflammatory cytokines [19]. We could not find information on whether this process also phosphorylates and activates receptor tyrosine kinases that promote pruritus, such as the IL-31 receptor or the tropomyosin-related kinase A (TrkA) receptor (See Table 1) $[1 \bullet, 4 \bullet, 5,26,27]$. However, if they are activated, then this might be a mechanism by which $\mathrm{HOCl}$ could actually increase pruritus.

\section{Safety of HOCl: Conditions Under which HOCI May Promote Pruritus as an Adverse Effect}

$\mathrm{HOCl}$ can promote pruritus as an adverse effect under certain conditions, which should be taken into account to ensure patient safety. As mentioned above, $\mathrm{HOCl}$ increases the activity of NGF, which promotes itch and is associated with atopic dermatitis, psoriasis, and prurigo nodularis (See Table 1) $[4 \cdot, 5]$. Topical $\mathrm{HOCl}$ treatment may also exacerbate pruritus because high-dose or prolonged cutaneous $\mathrm{HOCl}$ exposure can cause skin diseases of which pruritus is a principal symptom [7, 28]. Among these pruritic diseases, irritant contact dermatitis is most common, followed by allergic contact dermatitis (which is a Type IV hypersensitivity reaction to cutaneous $\mathrm{HOCl}$ exposure) [7, 28]. Even rarer are cases of Type I hypersensitivity reaction to cutaneous or systemic $\mathrm{HOCl}$ exposure, of which immunologic contact urticaria (ICU) is the major symptom [7, 28, 29]. Both the Type IV and Type I HOCl-induced hypersensitivity reactions occur following initial sensitization to $\mathrm{HOCl}$, which can happen in response to high-dose or prolonged cutaneous or systemic exposure to
$\mathrm{HOCl}$ (during which the patient may experience irritant contact dermatitis) [7]. In addition to rare instances of Type I hypersensitivity reaction, rare cases of $\mathrm{HOCl}$-induced nonimmunologic contact urticaria (NICU) have been reported $[7,28,29]$. Therefore, before treatment with $\mathrm{HOCl}$ is initiated, it is recommended that the patient receive an open skin test or a skin prick test, in order to detect HOCl-induced Type I hypersensitivity reaction (including ICU) or $\mathrm{HOCl}$-induced NICU [7, 29]. If the test result is negative, the patient should then be patch tested for HOCl-induced Type IV hypersensitivity reaction [7, 12]. In these tests, avoid using high concentrations and/or volumes of $\mathrm{HOCl}$, which can cause irritant contact dermatitis, resulting in false positive test results [12].

Irritant Contact Dermatitis (ICD) due to $\mathrm{HOCl}$

$\mathrm{HOCl}$ is a well-known cause of irritant contact dermatitis (ICD) [28]. As demonstrated by several clinical studies, the degree of skin irritation in HOCl-induced ICD depends upon duration of cutaneous exposure to $\mathrm{HOCl}$ and $-\mathrm{OCl}$, the combined amount of $\mathrm{HOCl}$ and $-\mathrm{OCl}$ to which a given area of skin is exposed, and the $\mathrm{pH}$ of the $\mathrm{HOCl}$ solution in the epidermis.

Duration of $\mathrm{HOCl}$ exposure and $\mathrm{HOCl}$ concentration play significant roles in the pathogenesis of $\mathrm{HOCl}$-induced ICD, as demonstrated by Goffin et al. [30] in a double-blind, placebo-controlled trial of 15 adult female human subjects with normal skin [30]. Damage to the stratum corneum is often the first step in the pathogenesis of ICD [30]. Goffin et al. [30] provided evidence that this is true in HOClinduced ICD by showing that damage to the stratum corneum (but probably not more deeply located parts of the skin) caused the first subclinical signs of cutaneous irritation following $\mathrm{HOCl}$ patch testing of brief but varying durations (ranging from 15 to 90 minutes) [30]. Longer duration of $\mathrm{HOCl}$ exposure and higher $\mathrm{HOCl}$ concentration increased stratum corneum damage, thereby increasing the severity of these initial subclinical signs [30]. For example, longer duration of cutaneous exposure to $4 \% \mathrm{NaOCl}$ solution caused an increase in squamometry index in vivo, indicating decreased strength of adhesion between corneocytes in the stratum corneum [30]. Longer duration of exposure to $4 \%$ $\mathrm{NaOCl}$ solution may have also reduced skin capacitance in vivo, indicating loss of $\mathrm{H}_{2} \mathrm{O}$ from the stratum corneum $[30,31]$. Ex vivo corneosurfametry also showed that solutions with higher $\% \mathrm{NaOCl}$ had increased reactivity with the stratum corneum [30]. Unfortunately, the relationship between $\mathrm{pH}$ of $\mathrm{HOCl}$ solution and stratum corneum damage was not explored by Goffin et al. [30] and requires further study.

As mentioned above, the combined amount of $\mathrm{HOCl}$ and $\mathrm{OCl}$ to which a given area of skin is exposed is a significant determinant of the degree of skin irritation seen clinically. In a 
non-blinded, controlled trial of 50 adult human subjects without skin disease, Hostynek et al. [12] evaluated degree of skin irritation (measured both by a 5-point visual erythema scale and by red hue detected by a skin color reflectance meter) following a 24-hour patch test in which $\mathrm{HOCl}$ solutions of varying $\mathrm{pH}$ levels and varying volumes were applied to a given area of skin [12]. The sum of the molar concentrations of $\mathrm{HOCl}$ and $-\mathrm{OCl}$ (which we denote as $\mathrm{C}$ ) was held constant at $1.36 \times 10^{-7} \mathrm{~mol} / \mu \mathrm{L}$ (which is equivalent to $1 \mathrm{wt} \% \mathrm{NaOCl}$ ) [12]. This study found that degree of skin irritation is an increasing function of the volume of $\mathrm{HOCl}$ solution applied to the skin area under the patch $\left(\mathrm{V}_{\text {patch }}\right)$ [12]. Other reports indicate that degree of skin irritation is also an increasing function of $\mathrm{C}[23 \cdot \bullet, 32]$. Values of $\mathrm{C}$ corresponding to $\%$ $\mathrm{NaOCl}$ above $0.5 \%$ can cause irritation $[33,34]$. We believe that the following hypothesis generalizes these results: Skin irritation is an increasing function of the combined number of moles of $\mathrm{HOCl}$ and $-\mathrm{OCl}$ applied to a given area of skin $\left(\mathrm{C} \times \mathrm{V}_{\text {patch }}\right)$.

The $\mathrm{pH}$ of the $\mathrm{HOCl}$ solution in the epidermis is another important determinant of the degree of skin irritation. We define $\mathrm{pH}_{\max }$ as the $\mathrm{pH}$ of $\mathrm{HOCl}$ solution in the epidermis at which skin irritation reaches a maximum. Hostynek et al. [12] determined that, when $\mathrm{C} \times \mathrm{V}_{\text {patch }}$ is held constant at $1.36 \times 10^{-7} \mathrm{~mol} / \mu \mathrm{L} \times 100 \mu \mathrm{L}$, then $\mathrm{pH}_{\text {max }} \approx 8$ [12]. When $\mathrm{pH}$ in the epidermis rises above $\mathrm{pH}_{\max }=8$, skin irritation decreases because $\mathrm{HOCl}$, which is more irritating to skin (because it is more reactive, as mentioned above), is deprotonated and forms - $\mathrm{OCl}$, which is less irritating to skin [12]. When $\mathrm{pH}$ in the epidermis decreases below $\mathrm{pH}_{\max }=8$, the decrease in $\mathrm{pH}$ itself becomes the dominant factor and causes a reduction in skin irritation [12]. We speculate that the decrease in skin irritation occurs because lower $\mathrm{pH}$ in the epidermis results in decreased activity of serine proteases, thereby decreasing activation of the PAR2 receptor (which is discussed in Tables 1 and 2) $[2 \cdot \bullet, 5,35]$. We also suspect that $\mathrm{pH}_{\max }$ is not constant at 8 , but instead depends upon $\mathrm{C} \times \mathrm{V}_{\text {patch. }}$. For example, when $\mathrm{C} \times \mathrm{V}_{\text {patch }}$ is held constant at a very low level near 0 , then, at any given $\mathrm{pH}$, a marginal increase in $\mathrm{pH}$ will have a small irritation-reducing effect by converting $\mathrm{HOCl}$ to $-\mathrm{OCl}$ and a large irritation-increasing effect by raising $\mathrm{pH}$. This implies that $\mathrm{pH}_{\max }$ (where these two effects balance each other) will be very high. In the extreme case, when $\mathrm{C} \times \mathrm{V}_{\text {patch }}=0$, then $\mathrm{pH}_{\max }$ is infinitely high. However, when $\mathrm{C} \times \mathrm{V}_{\text {patch }}$ is held constant at a very high level, then, at any given $\mathrm{pH}$, a marginal decrease in $\mathrm{pH}$ will have a large irritation-increasing effect by converting - $\mathrm{OCl}$ to $\mathrm{HOCl}$ and a small irritation-reducing effect by lowering $\mathrm{pH}$. This implies that $\mathrm{pH}_{\max }$ (where these two effects balance each other) will be very low. In the extreme case, when $\mathrm{C} \times \mathrm{V}_{\text {patch }}$ approaches infinity, then $\mathrm{pH}_{\max }$ is infinitely negative. Based on this reasoning, we propose the following hypothesis: $\mathrm{pH}_{\max }$ is a decreasing function of $\mathrm{C} \times \mathrm{V}_{\text {patch }}$.
The buffering capacity of the skin is another significant determinant of the degree of skin irritation in HOCl-induced ICD. The skin's buffering capacity causes basic $\mathrm{HOCl}$ solutions to have $\mathrm{pH}$ in the epidermis that is lower than their ex vivo $\mathrm{pH}$ and acidic $\mathrm{HOCl}$ solutions to have $\mathrm{pH}$ in the epidermis that is higher than their ex vivo $\mathrm{pH}[12,36]$. However, the magnitude of this buffering effect decreases if the buffering capacity is overcome, which can occur due to any of the following: 1) very high amounts of basic or acidic solution are applied to a given area of skin (that is, $\mathrm{C} \times \mathrm{V}_{\text {patch }}$ is very high);2) solutions with very high ex vivo $\mathrm{pH}$ or very low ex vivo $\mathrm{pH}$ are applied to skin [12]. If $\mathrm{pH}_{\max }$ is within the buffer range of the skin, then the skin's buffering capacity pulls the $\mathrm{pH}$ of the $\mathrm{HOCl}$ solution in the epidermis closer to $\mathrm{pH}_{\max }$, thereby increasing skin irritation [12]. In this case, skin irritation may paradoxically decrease if the skin's buffering capacity is overcome either by high $\mathrm{C} \times \mathrm{V}_{\text {patch }}$ or by extremes of ex vivo $\mathrm{pH}$ [12]. If $\mathrm{pH}_{\max }$ is outside of the buffer range of the skin, then the skin's buffering capacity pulls the $\mathrm{pH}$ of the $\mathrm{HOCl}$ solution in the epidermis farther away from $\mathrm{pH}_{\max }$, thereby decreasing skin irritation [12]. In this case, skin irritation increases if the skin's buffering capacity is overcome either by high $\mathrm{C} \times \mathrm{V}_{\text {patch }}$ or by extremes of ex vivo $\mathrm{pH}$ [12].

\section{Conclusion}

Using available literature on pruritus and literature on $\mathrm{HOCl}$, we have proposed mechanisms by which $\mathrm{HOCl}$ may have anti-pruritic effects, as well as conditions under which $\mathrm{HOCl}$ may actually cause pruritus. $\mathrm{HOCl}$ may reduce pruritus either through its microbicidal effects upon cutaneous pathogens (especially Staphylococcus aureus in atopic dermatitis $\left.\left[3 \bullet^{\circ}\right]\right)$ or through its anti-inflammatory effects (especially reduction in the activities of histamine, LTB4, and IL-2, all of which have been implicated in the pathophysiology of itch $[1 \bullet, 4 \bullet, 5,6 \bullet])$. However, $\mathrm{HOCl}$ may promote pruritus by increasing the activity of NGF $[4 \cdot, 5]$. Prolonged exposure or high doses of $\mathrm{HOCl}$ may also promote pruritus as an adverse effect by causing irritant contact dermatitis, or less commonly allergic contact dermatitis (which is a Type IV hypersensitivity reaction) [7]. Currently, there is a dearth of available research on the relationship between $\mathrm{HOCl}$ and pruritus, and we look forward to future studies that will test and elaborate on the hypotheses proposed in this paper.

\section{Compliance with Ethics Guidelines}

Conflict of Interest RY Pelgrift declares no conflicts of interest. AJ Friedman declares no conflicts of interest.

Human and Animal Rights and Informed Consent This article does not contain any studies with human or animal subjects performed by any of the authors. 


\section{References}

Papers of particular interest, published recently, have been highlighted as:

- Of importance

•- Of major importance

1. - Garibyan L, Rheingold CG, Lerner EA. Understanding the pathophysiology of itch. Dermatol Ther. 2013;26(2):84-91. This is the most recently published review article on the pathophysiology of itch that was used as a source for this paper. It discusses the four types of pruritus, focusing on pruritoceptive itch, its neuroanatomy, and its chemical mediators.

2. •- Patel T, Yosipovitch G. Therapy of pruritus. Expet Opin Pharmacother. 2010;11(10):1673-82. This review article gives an overview of current pharmacologic therapy of pruritus and is the major source of information on this topic used in this paper, especially Table 2. The article discusses topical and systemic treatments of pruritus, including their mechanisms of action, pruritic diseases for which they are indicated, and adverse effects.

3. . Draelos Z, Cash K. Evaluation of a Gel Formulation of Hypochlorous Acid and Sodium Hypochlorite to Reduce Pruritus in Mild to Moderate Atopic Dermatitis. Poster. Presented at Winter Clinical Dermatology Meeting, Maui, HI, January, 2012. This poster is the only clinical study performed to date specifically testing the effect of topical HOCl treatment on severity of pruritus. In this case series (which lacked controls) of 20 human subjects with atopic dermatitis, there were statistically significant reductions in pruritus at day 3 of treatment with topical $\mathrm{HOCl}$.

4. - Greaves MW. Pathogenesis and treatment of pruritus. Curr Allergy Asthma Rep. 2010;10(4):236-42. This review article gives an overview of the pathophysiology of itch, including the four types of pruritus, neurophysiology of pruritus, and mediators of itch. The article concludes by relating these concepts to systemic pharmacologic therapy of pruritus.

5. Yosipovitch G, Papoiu AD. What causes itch in atopic dermatitis? Curr Allergy Asthma Rep. 2008;8(4):306-11.

6. - Friedman AJ, Cash K, Berman B. Hypochlorous Acid is Antiinflammatory and Immunomodulatory. Poster. Presented at the Winter Clinical Dermatology Conference, Kauai, HI, January 18, 2013. This poster gives an overview of the anti-inflammatory effects of HOCl and suggests that they may serve as a mechanism by which $\mathrm{HOCl}$ could reduce pruritus.

7. Hostynek JJ, Patrick E, Younger B, Maibach HI. Hypochlorite sensitivity in man. Contact Dermatitis. 1989;20(1):32-7.

8. Twycross R, Greaves MW, Handwerker H, et al. Itch: scratching more than the surface. QJM. 2003;96(1):7-26.

9. Han L, Ma C, Liu Q, et al. A subpopulation of nociceptors specifically linked to itch. Nat Neurosci. 2012;16(2):174-82.

10. Chang SE, Han SS, Jung HJ, Choi JH. Neuropeptides and their receptors in psoriatic skin in relation to pruritus. Br J Dermatol. 2007;156(6):1272-7.

11. Wang L, Bassiri M, Najafi R, et al. Hypochlorous acid as a potential wound care agent: part I. Stabilized hypochlorous acid: a component of the inorganic armamentarium of innate immunity. J Burns Wounds. 2007;6:e5.

12. Hostynek JJ, Wilhelm KP, Cua A, Maibach HI. Irritation factors of sodium hypochlorite solutions in human skin. Contact Dermatitis. 1990;23(5):316-24.

13. Awad S, Allison SP, Lobo DN. The history of $0.9 \%$ saline. Clin Nutr. 2008;27(2):179-88.

14. Harris DC. Exploring Chemical Analysis. 5th ed. New York: WH Freeman; 2012. p. 20.
15. Auerstat ${ }^{\mathrm{TM}}$ : Skin \& Wound Hydrogel. Onset Dermatologics. Available at http://www.onsetdermatologics.com/sites/default/files/ Aurstat Labeling 2148-pf-Rev-2W-07-1.pdf. Accessed May 2013.

16. Klebanoff SJ. Myeloperoxidase: friend and foe. J Leukoc Biol. 2005;77(5):598-625.

17. Hampton MB, Kettle AJ, Winterbourn CC. Inside the neutrophil phagosome: oxidants, myeloperoxidase, and bacterial killing. Blood. 1998;92(9):3007-17.

18. - Winterbourn CC, Kettle AJ. Redox reactions and microbial killing in the neutrophil phagosome. Antioxid Redox Signal. 2013;18(6):64260. This review article gives a very detailed overview of the biochemistry of $\mathrm{HOCl}$ synthesis in the phagosome during the respiratory burst. The article also briefly discusses the biochemistry of microbial killing by $\mathrm{HOCl}$.

19. Mainnemare A, Megarbane B, Soueidan A, et al. Hypochlorous acid and taurine-N-monochloramine in periodontal diseases. J Dent Res. 2004;83(11):823-31.

20. Maitra D, Byun J, Andreana PR, et al. Reaction of hemoglobin with $\mathrm{HOCl}$ : mechanism of heme destruction and free iron release. Free Radic Biol Med. 2011;51(2):374-86.

21. Albrich JM, McCarthy CA, Hurst JK. Biological reactivity of hypochlorous acid: implications for microbicidal mechanisms of leukocyte myeloperoxidase. Proc Natl Acad Sci. 1981;78(1): $210-4$.

22. Po HN, Senozan NM. The Henderson-Hasselbalch equation: its history and limitations. J Chem Educ. 2001;78:1499-503.

23. • Barnes TM, Greive KA. Use of bleach baths for the treatment of infected atopic eczema. Australas J Dermatol 2013. This review article summarizes the current literature on use of dilute bleach baths to treat Staphylococcus aureus overgrowth in atopic dermatitis. The article summarizes the four clinical studies performed to date on this subject. The article also discusses the pathophysiology of exacerbations of atopic dermatitis secondary to Staphylococcus aureus overgrowth.

24. Li MO, Wan YY, Sanjabi S, et al. Transforming growth factor$\beta$ regulation of immune responses. Annu Rev Immunol. 2006;24:99-146.

25. Tatsumi T, Fliss H. Hypochlorous acid and chloramines increase endothelial permeability: possible involvement of cellular zinc. Am J Physiol Heart Circ Physiol. 1994;267(4): H1597-607.

26. Nobbe S, Dziunycz P, Muhleisen B, et al. IL-31 expression by inflammatory cells is preferentially elevated in atopic dermatitis. Acta Derm Venereol. 2006;92(1):3-4. 24-28.

27. Johansson O, Liang Y, Emtestam L. Increased nerve growth factorand tyrosine kinase A-like immunoreactivities in prurigo nodularis skin-an exploration of the cause of neurohyperplasia. Arch Dermatol Res. 2002;293(12):614-9.

28. Wolff K, Johnson RA. Fitzpatrick's Color Atlas and Synopsis of Clinical Dermatology.6th ed. New York: McGraw Hill; 2009:21, $32,358-365$.

29. Wakelin SH. Contact urticaria. Clin Exp Dermatol. 2001; 26(2):132-6.

30. Goffin V, Piérard GE, Henry F, et al. Sodium hypochlorite, bleaching agents, and the stratum corneum. Ecotoxicol Environ Saf. 1997;37(3):199-202.

31. Clarys P, Barel AO, Gabard B. Non-invasive electrical measurements for the evaluation of the hydration state of the skin: comparison between three conventional instruments-the Corneometer ${ }^{\mathbb{B}}$, the Skicon ${ }^{\circledR}$ and the Nova DPM ${ }^{\mathbb{B}}$. Skin Res Tech. 1999;5(1):14-20.

32. Racioppi F, Daskaleros PA, Besbelli N, et al. Household bleaches based on sodium hypochlorite: review of acute toxicology and poison control center experience. Food Chem Toxicol. 1994;32(9):845-61. 
33. Peck B, Workeneh B, Kadikoy H, et al. Spectrum of sodium hypochlorite toxicity in man-also a concern for nephrologists. NDT Plus. 2011;4(4):231-5.

34. Sherman WO. Sterilization of wounds, treatment of suppurating wounds and osteomyelitis (carrel method). Proc Roy Soc Med. 1917;10(Section of Surgery):1-28.

35. Seeliger S, Derian CK, Vergnolle N, et al. Proinflammatory role of proteinase-activated receptor- 2 in humans and mice during cutaneous inflammation in vivo. FASEB J. 2003;17(13): 1871-85.

36. Levin J, Maibach H. Human skin buffering capacity: an overview. Skin Res Tech. 2008;14(2):121-6.
37. Andoh T, Saito A, Kuraishi Y. Leukotriene B4 mediates sphingosylphosphorylcholine-induced itch-associated responses in mouse skin. J Investig Dermatol. 2009;129(12):2854-60.

38. Katzung BG, Masters SB, Trevor AJ. Basic \& Clinical Pharmacology. 12th ed. New York: McGraw Hill Medical; 2012:24 - 26, 275, $277-278,307,319,546,643-644,988,1076$.

39. Demierre MF, Taverna J. Mirtazapine and gabapentin for reducing pruritus in cutaneous T-cell lymphoma. J Am Acad Dermatol. 2006;55(3):543-4.

40. Reddy VB, Iuga AO, Shimada SG, et al. Cowhage-evoked itch is mediated by a novel cysteine protease: a ligand of proteaseactivated receptors. J Neurosci. 2008;28(17):4331-5. 